ECOLOGICA, Vol. 28, No 104 (2021), 581-590

https://doi.org/10.18485/ecologica.2021.28.104.13

Originalni naučni rad

UDC: $338.43(497.11)^{\prime \prime 2} 2000 / 2021^{\prime \prime}$

\title{
Mesto i značaj agroprivrede u ekonomskom sistemu Republike Srbije od 2000. do 2021. godine
}

\section{The place and importance of agriculture in the economic system of the Republic of Serbia from 2000 to 2021}

\author{
Andrija Blanuša ${ }^{1 *}$, Slobodan Petrović ${ }^{2}$, Mirjana Stevanović ${ }^{3}$ \\ 1,2Fakultet društvenih nauka, Univerzitet privredna akademija u Novom Sadu, Beograd, Srbija / \\ Faculty of Social Sciences, University Business Academy in Novi Sad, Belgrade, Serbia \\ ${ }^{3}$ Visoka poslovna škola strukovnih studija prof. dr Radomir Bojković, Kruševac, Srbija / \\ Business College of Applied Studies „Prof. PhD Radomir Bojković“ Kruševac, Serbia \\ ${ }^{*}$ Autor za prepisku / Corresponding author
}

Rad primljen / Received: 05.09.2021, Rad prihvaćen / Accepted: 09.10.2021.

Sažetak: Ovaj istraživački rad jasno i nedvosmisleno prikazuje položaj, a prema položaju i značaj agroprivrede u ekonomskom sistemu Republike Srbije današnjice. Autori posebnu pažnju obraćaju na deskriptivnu analizu pravnih dokumenata donetih u periodu od 2000. godine do danas, što upućuje na iskazivanje činjenica od prioriteta za razvoj agrara, a prema donetim Strategijama razvoja i drugim vitalnim dokumentima. Kvalitativnim i kvantitativnim metodom istraživanja i analizom pozitivnih dokumenata u oblasti istraživanja, autori su izveli određene konkluzije koje su prikazali u radu. Klasifikacijom selektovanih podataka autori su u konkluziji izneli predloge reforme činilaca i subjekata koji utiču na poziciju agrara u Republici Srbiji. Tabelarno i putem grafikona prikazani su tokovi kretanja budžetskih izdvajanja za poljoprivredu, kao i mere koje podstiču razvoj agrarne politike Republike Srbije.

Ključne reči: agroprivreda, ekonomski sistem, Republika Srbija, mere agrarne politike, strategija razvoja poljoprivrede.

\begin{abstract}
This research work clearly and unambiguously shows the position, and according to the position, the importance of agronomy in the economic system of the Republic of Serbia today. The authors pay special attention to the descriptive analysis of legal documents adopted in the period from 2000 until today, which indicates the presentation of facts from the priorities for the development of agriculture, and according to the adopted Development Strategies and other vital documents. By qualitative and quantitative research method and analysis of positive documents in the field of research, the authors made certain conclusions that they presented in the paper. By classifying the selected data, the authors concluded the proposals for the reform of factors and entities that affect the position of agriculture in the Republic of Serbia. Tables and graphs show the flows of budget allocations for agriculture, as well as measures that encourage the development of agricultural policy of the Republic of Serbia.
\end{abstract}

Keywords: agricultural economy, economic system, Republic of Serbia, agricultural policy measures, agricultural development strategy.

\footnotetext{
10rcid.org/0000-0001-8317-9285, e-mail: andrijasn3@gmail.com

20rcid.org/0000-0002-9343-5999, e-mail: slobpetrovic@yahoo.de

3orcid.org/0000-0002-3520-1350, e-mail: mira.stev@mts.rs
} 


\section{UVOD / INTRODUCTION}

Agrarna privreda Republike Srbije je najstarija nacionalna delatnost sa najlošijom pozicijom u poslednjih sto godina postojanja i stvaralačkog nastojanja nacije. Za vreme monarhije Srbija se ubrajala $u$ srednje razvijene poljoprivredne države, da bi za vreme komunizma s puno napora postala srednje razvijena industrijska država koja u tom trenutku ima neuporedivo veći broj stanovnika, te na kraju, po izlasku iz jednopartijskog režima ona doživljava apsolutni krah poljoprivrede kao osnovne državne delatnosti svake države na svetu. Po geografskom položaju Republika Srbija ima područja i ekstenzivnog i intenzivnog tipa razvoja poljoprivrednog područja. Po meliorizaciji zemljišta, smatra se, da je samo AP Vojvodina toliko plodna ravnica da bi mogla da snabdeva poljoprivrednim proizvodima pola Evrope. Permanentan i višedecenijski nepovoljan položaj poljoprivrede u Republici Srbiji rezultirao je pogrešnom i nedovoljno kompetentnom sistematskom odnosu svake aktuelne Vlade prema sektoru najstarije delatnosti čovečanstva. Umesto da se ulaže (investira) u ovu stratešku privrednu granu, sa izrazitim komparativnim prednostima, u Srbiji se odvija retrogradni proces - dezinvestiranja (Pejanović i dr, 2009). Svi periodi odnosno faze kroz koje prolazi poljoprivreda karakteristični su za države nestabilnih institucija, neizgrađenog državnog aparata, odsustva državnog intervencionalizma, pa samim tim ovakav položaj poljoprivrede kakav danas imamo i nije toliko začuđujuć, jer proces deagrarizacije agresivno razara agrarnu politiku i destimulativno utiče na poljoprivredne proizvođače. Država pokušava da putem različitih mera agrarne politike doprinese revitalizaciji ove izuzetno značajne grane privrede, ali ni jedna mera do sada nije dala merljive rezultate. Ono što bi revitalizovalo poljoprivrednu proizvodnju Republike Srbije, a samim tim i Republiku Srbiju, jer je poljoprivreda osnova svakog razvijenog nacionalnog društva, sa ovakvim ili sličnim geografskim odlikama, jeste merkantilistička ekonomska politika, ulaganje u mehanizaciju, razvoj poljoprivredne infrastrukture, stimulans države za podizanje nivoa motivisanosti nosilaca poljoprivrednih gazdinstava. $\mathrm{Na}$ osnovu indikatora i stanja poljoprivrede Republike Srbije može se lako zaključiti da jedino nasleđe iz ne tako davnih vremena, svaka Vlada vidi kao „nasleđeni problem". Poljoprivreda i selo danas, posebno u okolnostima svetske ekonomske krize, zauzimaju značajnu ulogu u sveukupnom privređivanju Republike Srbije.
1. MERE AGRARNE POLITIKE U REPUBLICI SRBIJI OD 2000. GODINE DO DANAS / AGRICULTURAL POLICY MEASURES IN THE REPUBLIC OF SERBIA FROM 2000 TO THE PRESENT

Pošto agrarna politika spada u red javnih politika, odnosno politika koje kreira Vlada Republike Srbije, na taj način se i na nju odnose i utiču mnogi faktori koji je bliže određuju i u potpunosti uređuju. U prilog tome, važno je napomenuti da je ovaj organ izvršne vlasti taj koji može u svim oblastima društvenog života donositi važne akte ili predlagati njihovo donošenje, a naša obaveza je da in se u potpunosti pridržavamo. U skladu $\mathrm{s}$ tim, da bi više materijalnih sredstava ulagao u brojne svoje aktivnosti, mora da uvede poreze kako bi finansirao javne potrebe, a samim tim i javne politike i sve njene potpolitike.

Vlada aktivno može učestvovati i uticati na agrarnu politiku tako što će uvoditi subvencije za građane i privredu, naročito onda kada je to u društvenom interesu da se zaštite građani i privreda kako bi se podržale investicije i zapošljavanje, izgradila infrastruktura, obezbedili obrazovanje, zdravstvo, kultura itd. Država, takođe, može da pruža određene usluge privredi, preko javnih preduzeća, ustanova i agencija u njenom vlasništvu, a kada ih obezbeđuje privatni sektor ona ih onda finansira i kontroliše.

Glavni zadatak Vlade je da pronađe mesta intervencije, odnosno tačke na kojima je moguće ostvariti bitne i željene promene u oblasti agrarne politike, kako bi je kontinuirano unapređivali i osavremenjivali. Te važne tačke promena se najčešće javljaju u vidu zakona i pravila, promena organizacija koje utiču na agrarnu politiku u vidu ministarstava, institucija, agencija i dr., kao i podsticanjem, jačanjem i preusmeravanjem već započetih delatnosti kao što su privatizacije, preduzetništva i decentralizacije. Zato je važno da oni koji se u državi bave ovim poslovima, i koji su zaduženi za agrarnu politiku, svoju aktivnost i delovanje $u$ ovoj oblasti zasnivaju na znanju $i$ istraživanju koji se odnose na agrarne poslove $\mathrm{i}$ agrarnu politiku.

Analiziranjem stanja privrede, a samim tim i poljoprivrede, jedne države mogu se saznati problemi i razlozi nedovoljne uređenosti određene oblasti i smanjene efikasnosti iste. Analizom se može utvrditi sadržaj agrarne politike tako što će moći da se opiše problem koji je nastao i koji se mora rešiti. Najpre, otkriti uzroke nastanka određene agrarne politike i aktivnost koja se mora obaviti kako bi ta politika bila uspešna, odnosno efikasna. U svakoj aktivnosti vezanoj za agrarnu politiku se mora obratiti pažnja i delovati tako da posledice koje proizilaze iz sprovođenja javne politike budu što pozitivnije i efektivnije. 
A možemo reći da je poželjno da budu i što ekonomičnije.

Raznim aktivnostima i analizama možemo doprineti otkrivanju razloga i determinanata agrarne politike, zašto je ona baš takva kao što jeste, koji su razlozi da vlada čini to što čini, koliko je partijski uticaj na vladu u ovom slučaju, koji su efekti socijalni, ekonomski i kulturni u oblikovanju jedne agrarne politike. Naročito kada je u pitanju smanjenje budžetskih sredstava i starost populacije koja se bavi ovom vrstom javne politike. Važno je nakon svega utvrditi i potvrditi uticaj i efekte agrarne politike odnosno donetih odluka vezanih za ovu oblast od strane države. Konstantno treba postavljati pitanje i analizirati da li je neka doneta odluka postigla očekivane rezultate i da li su posledice takve politike donele željene ili neželjene efekte.

Agrarna politika je skup mera ekonomske politike, koji obuhvata celokupnu aktivnost njenih nosilaca usmerenu ka poljoprivredi. Ekonomski sistem koji u dovoljnoj meri ne vrednuje prirodne resurse i pri tome stimuliše neograničen ekonomski rast, dugoročno je neodrživ. Ekonomski aspekti i prednosti korišćenja prirodnih resursa odnose se prvenstveno na korišćenje lokalnih izvora, povećavajući na taj način stepen zaposlenosti i prelivanje sredstava ka drugim privrednim granama (Žikić i dr., 2021). Agrarna politika se najčešće definiše kao svesno usmerena akcija vlade realizovana u prehrambenom sektoru kako bi ograničeni resursi bili optimalno iskorišćeni u cilju ostvarivanja rezultata proizvodnje koji su u skladu sa društvenim uverenjem „šta bi trebalo da bude". U tom smislu, agrarna politika je usmerena ka stvranju idealnog prehrambenog sistema koji treba da obezbedi realizaciju miksa raznorodnih ciljeva sagledanih kroz potrebu obezbeđenja: adekvatne hrane za sve; jeftine hrane; dostupne hrane u toku godine; zdravstveno bezbedne hrane; i odgovarajućeg načina života za poljoprivredne proizvođače (Drummond et al., 2001)

Iz pomenutog možemo zaključiti da je proces donošenja agrarne politike veoma kompleksan i spor i da zahteva aktivnost velikog broja aktera i institucija. Čim se definiše neki problem nastao u agrosistemu, automatski se pristupa izradi mogućih akcija koje taj problem mogu rešiti, što znači da se pristupa jednoj novoj, efikasnijoj agrarnoj politici. U tom trenutku nastupaju vlasti države koje moraju zvanično da usvoje jednu takvu politiku, kako bi ona mogla da deluje. Nakon toga sledi sprovođenje, odnosno implementacija takve politike sa ciljem ostvarivanja onih aktivnosti za koje se smatra da će doneti napredak agrarnom sistemu Republike Srbije. Poslednji korak u ostvarivanju jedne agrarne politike jeste njena evaluacija, kako bi se utvrdili efekti ove politike i njena opravdanost u sistemu donošenja odluka koje utiču na razvoj agrarne politike. Analiza ovakve politike neretko daje neočekivane rezultate jer se može desiti da politika ne funkcioniše onako kako je predviđeno.

U periodu početkom 2000-ih godina agrarna politika bila je u najvećoj meri usmerena na rešavanje problema agrara i saniranje veoma teškog stanja koje je zatečeno nakon ratova i finansijskih poteškoća ' 90 ih uz velike varijacije i trendove opadanja učešća agrarnog budžeta u oslabljenom budžetu R. Srbije.

Od 2004. godine u agrarnoj politici načinjen je ozbiljan zaokret u strateškim pravcima i mehanizmima primene: podrška je usmerena samo na registrovana poljoprivredna gazdinstva i izvedena je diversifikacija mera podrške usmerenih na rast konkurentnosti porodičnih komercijalnih gazdinstava, uz izmenu mehanizama podrške, sa politike podsticaja cenama (i dohotku), na podsticaje investicija.

U narednim godinama donosi se Strategija razvoja poljoprivrede (2005), a od 2007. godine u većoj je meri zastupljen sistem (direktnih) plaćanja po hektaru zasejane površine, odnosno, grlu stoke, povećava se podrška investicijama i modernizaciji i ruralnom razvoju. Srbija ima relativno dugu tradiciju politike u oblasti ruralnog i regionalnog razvoja, još iz perioda SFRJ u kojoj su postojali izraženi regionalni dispariteti u razvijenosti republike, kao i heterogenost u prirodnim resursima i u proizvodnim, ekonomskim i organizacionim parametrima poljoprivredne proizvodnje.

U narednom periodu država je insistirala na donošenju brojnih strategija za uređenje agrarne politike, odnosno za preporod poljoprivredne politike. $\mathrm{S}$ tim u vezi donose se preko potrebne strategije koje bi trebalo da doprinesu modernizaciji agrarne delatnosti. Mi ćemo se u ovom delu rada najviše osvrnuti na period od 2000. godine do danas. Zato izdvajamo sledeće strategije i dokumente koji na različite načine dotiču problem ruralnih područja i poljoprivrede: Strategija razvoja poljoprivrede (2005.); Strategija ruralnog razvoja Srbije za period 2007-2012 godine; Strategija smanjenja siromaštva (2003. godine); Nacionalna strategija zapošljavanja za period 2005-2015 i period 2011-2020 godine, kao i period 2021-2026 godine; Zakon o poljoprivredi i ruralnom razvoju; Nacionalni plan za poljoprivredu; Nacionalni program za poljoprivredu Republike Srbije od 2010. do 2013. godine; i Strategija poljoprivrede i ruralnog razvoja Republike Srbije za period 2014-2024 godine.

Svi ovi akti su pokazali spremnost države da se preduzmu veliki koraci u smeru razvoja poljoprivrede, osavremenjivanja ruralnih područja, smanjenja siromaštva, kao i gorući problem u državi a to je spremnost i pokušaj da se na razne načine smanji stopa siromaštva građana koji na ovom prostoru žive. 
Upravo će nam ovi akti pokazati na kakve se korake država odlučila povodom rešavanja problema u ovim oblastima agrarne politike.

Akt koji je među prvima donet u periodu od 2000. godine do danas, a za naš rad je veoma važan, jeste Strategija razvoja poljoprivrede iz 2005. godine. Videćemo u narednom delu koja je svrha ove Strategije i šta je država želela da uradi i šta joj je bio cilj pri donošenju Strategije kada je u pitanju uspostavljanje tržišne ekonomije. Prema tome, cilj ove strategije, koji je identičan cilju Strategije EU, jeste da se progresivno reformiše sistem carinske zaštite i domaćih subvencija u Srbiji tako da one imaju sve manje uticaja na odluku proizvođača šta da proizvode, ostavljajući im slobodu praćenja tržišta i izbora načina prilagođavanja tom tržištu (Strategija, 2005).

U prvoj fazi ovih reformi postojeće subvencije će se smanjivati i sredstva će se preusmeravati ka investicijama koje će poljoprivredu u Srbiji učiniti profitabilnijom (bespovratna sredstva, krediti, subvencije inputa i dr.). Neki od ovih oblika podrške, kao npr. krediti, biće potpuno neutralan i neće davati instrukciju šta bi to proizvođač trebalo da proizvodi, dok će bespovratna sredstava i podrška inputima biti više usmerena na određene proizvode. Sve mogućnosti podrške moraju biti publikovane i dostupne svima, tako da proizvođači mogu da imaju potpunu informaciju kad odlučuju šta će proizvoditi. U sledećoj fazi reforme, smanjiće se i subvencije za inpute jer će se to zahtevati od Srbije po pristupu STO i programi dodele bespovratnih sredstava će biti povećani $i$ usmereni na razvoj sela, na isti način kako je to trend i u EU, što će imati za posledicu dalje slabljenje veze između podrške države i odluke proizvođača šta da proizvodi (Strategija, 2005).

U trećoj fazi, koja će se završiti pridruživanjem EU, u Srbiji će biti stvoreni uslovi za prihvatanje sistema podrške SAR, koje će se tada primenjivati. Sistemi podrške tada će najverovatnije biti koncentrisani na sistem plaćanja po jedinici površine i vezani za različite kriterijume zaštite životne sredine, ali ni na koji način vezane za odluke proizvođača šta da proizvode (Strategija, 2005).

Poruka koja se šalje ovom Strategijom prvenstveno je usmerena na nužnost tehnološkog razvoja mehanizacije kako bi se postigla kontinuirana unapređenja u proizvodnji i kako bi se povećavala efikasnost u skoro svakoj sferi ekonomske delatnosti. Što se poljoprivrede tiče, gore pomenuto se može odražavati na više načina: Prvi je da napredak u sektoru mehanizacije omogućava čoveku da obrađuje mnogo veće površine i da uzgaja veća stada stoke. Drugi način je da se povećava produktivnost po hektaru što znači da razvijene zemlje proizvode veće količine hrane a populacija im je sve manja. A najveći problem je trend pada cene poljoprivrednih proizvoda, što znači da će proizvođač morati da poveća svoje gazdinstvo kako bi obezbedio isti nivo zarade.

\section{MERE AGRARNE POLITIKE PREMA \\ STRATEGIJI RAZVOJA POLjOPRIVREDE REPUBLIKE SRBIJE / \\ AGRICULTURAL POLICY MEASURES \\ ACCORDING TO THE AGRICULTURAL \\ DEVELOPMENT STRATEGY OF THE REPUBLIC OF SERBIA}

Kako želimo da prikažemo mere agrarne politike u Republici Srbiji, moramo se prvenstveno osvrnuti na ciljeve koje je država želela da zacrta kroz ovu Strategiju. A samim tim videti i stanje i karakteristike poljoprivrede u našoj zemlji. Zbog svojih prirodnih karakteristika zemljišta, klime i vodnih resursa Srbija ima veliki potencijal u poljoprivrednom sektoru, koji nije u potpunosti iskorišćen. Uz adekvatnu agrarnu politiku, poljoprivreda može dati značajan doprinos ekonomskom razvoju zemlje. Ona je zbog svoje povezanosti i uticaja na ostale sektore izuzetno značajna za razvoj Srbije, s obzirom na to da zapošljava, direktno ili indirektno, veliki broj ljudi, učestvuje značajnim delom u spoljnoj trgovini, obezbeđuje prehrambenu sigurnost građana i doprinosi ruralnom razvoju i ekološkoj ravnoteži (Strategija, 2005).

Godine 2005, kada je doneta ova Strategija, poljoprivreda je u bruto nacionalnom dohotku učestvovala sa oko $21 \%$, zapošljavala više od $10 \%$ zaposlenih, a u izvozu učestvovala sa $26 \%$. Upravo nam ovi podaci govore da poljoprivredni sektor u Srbiji nije bio u stanju da se uključi u ravnopravnu utakmicu sa konkurencijom oličenom prvenstveno u zemljama EU. U Srbiji su to bile godine nastajanja privatizacije koja je bila spora, sa veoma malo stranih ulaganja, tako da je država još uvek predstavljala glavnog nosioca vlasništva u mnogim prerađivačkim fabrikama i većini kombinata. $U$ drugim privredama u tranziciji strana ulaganja uglavnom predstavljaju osnovni vid oživljavanja industrije. A najveći problem Srbije, kao jedne tranzicione države, je bio, a nažalost i sada je, što institucije koje pružaju podršku nisu na adekvatan način tehnički, organizaciono i kadrovski osposobljene.

Pošto smo napomenuli da Vlada donosi veći broj javnih politika i kako sve utiču jedne na druge tako i ciljevi razvoja poljoprivrede Srbije ne obuhvataju samo agrarne ciljeve već i ekonomske, socijalne, ekonomske i ekološke. Zbog razvoja celokupnog agrarnog sistema potrebno je da se:

- izgradi održiv i efikasan poljoprivredni sektor koji može da se takmiči na svetskom tržištu, doprinoseći porastu nacionalnog dohotka; 
- obezbedi hrana koja zadovoljava potrebe potrošača u pogledu kvaliteta i bezbednosti;

- osigura podrška životnom standardu za ljude koji zavise od poljoprivrede a nisu u stanju da svojim razvojem prate ekonomske reforme;

- osigura podrška održivom razvoju sela;

- sačuva životna sredina od uticaja efekata poljoprivredne proizvodnje;

- $\quad$ pripremi poljoprivreda Srbije za integraciju u EU;

- pripremi politika domaće podrške i trgovine u poljoprivredi za pravila STO (Strategija, 2005).

\section{AGRARNA POLITIKA REPUBLIKE SRBIJE U STRATEGIJI IZ 2014. GODINE / AGRICULTURAL POLICY OF THE REPUBLIC OF SERBIA IN THE 2014 STRATEGY}

Devet godina nakon Strategije iz 2005. godine došlo je donošenja nove strategije, od strane Ministarstva poljoprivrede i zaštite životne sredine, koja je doneta 2014. godine pod nazivom Strategija poljoprivrede i ruralnog razvoja Republike Srbije za period 2014-2024. godine. U njoj se naglašava važnost države u donošenju i sprovođenju agrarne politike i gde se pominje da svaka država ima odgovornost da definiše okvir političkih i institucionalnih promena koje doprinose efikasnijem razvoju poljoprivrednog sektora i blagostanju stanovnika iz ruralnih područja.

Da bi ovu svoju ulogu adekvatno ispunila, obaveza države je da stabilnom, dugoročnom i efikasnom politikom reaguje na aktuelne izazove. Povezivanje ekonomskih, ekoloških i društvenih faktora predstavlja nesumnjivo osnovu za realizaciju koncepta održivog razvoja (Žikić i dr., 2020). U tom smislu, izrada ove strategije motivisana je potrebom da se novim konceptom poljoprivredne politike reaguje na unutrašnje i spoljne izazove, kao što su:

1) potreba da se smanji zaostajanje u tehnološkom razvoju za konkurentskim zemljama i omogući efikasnije suočavanje poljoprivrednog sektora sa efektima klimatskih promena;

2) neophodnost povećanja efikasnosti prehrambenog lanca i konkurentnosti poljoprivredno-prehrambenog sektora;

3) obezbeđivanje stabilnog dohotka i poslovnog okruženja za poljoprivrednike i druge preduzetnike;

4) ostvarivanje ekonomskih, ekoloških i socijalnih ciljeva održivog razvoja, u čemu multifunkcionalna poljoprivreda i ruralni razvoj imaju posebno mesto;

5) spremnost da se odgovori na zahteve proizašle iz procesa priključivanja Svetskoj trgovinskoj organizaciji i pridruživanja Evropskoj uniji (Strategija, 2014).

Zbog svega ovoga potrebno je uhvatiti se u koštac sa svim izazovima i pokušati unaprediti agrarni sistem države kroz razne aktivnosti i formiranje institucija. Potrebno je prvenstveno izvršiti reformu poljoprivredne politike u smislu uvođenja instrumenata agrarne politike koji omogućavaju dinamično restrukturiranje sektora poljoprivrede sa težnjom približavanja evropskim integracijama i razvijanja moderne uloge države u upravljanju razvojem poljoprivrede i ruralnih sredina. Takođe, neophodno je i usvajanje i potpuna primena zakonodavnog okvira, kao i institucionalnih reformi koje bi omogućile ostvarivanje strateških ciljeva.

Tokom perioda tranzicije, u Srbiji se nije desila značajnija promena privredne strukture. Od početka XXI veka doprinos poljoprivrede BDP-u je opadao, prvenstveno kao posledica bržeg rasta aktivnosti u neproizvodnim sektorima (pre svega, trgovini). Međutim, udeo poljoprivrede u strukturi BDP privrede Republike Srbije je i dalje veoma visok. U odnosu na prosek zemalja EU, Republika Srbija ima značajno veće učešće sektora poljoprivrede u ukupnom BDP, a značajno niže učešće sektora usluga (Strategija, 2014).

Visok udeo poljoprivrede u strukturi BDP privrede Republike Srbije se može sa jedne strane pripisati bogatim prirodnim resursima i povoljnim klimatskim uslovima za poljoprivrednu proizvodnju, a sa druge strane sporijem procesu strukturnog reformisanja ostatka privrede i zastojima u tom procesu.

\section{REZULTATI I DISKUSIJA / RESULTS AND DISCUSSION}

Republika Srbija raspolaže sa 5,06 miliona hektara poljoprivrednog zemljišta, od čega se $71 \%$ površina koristi na intenzivan način (u vidu oranica, voćnjaka i vinograda), dok $29 \%$ poljoprivrednih površina čine prirodni travnjaci (livade i pašnjaci). Dominantan deo poljoprivrednih površina, 3,3 miliona hektara odnosno $65 \%$, koristi se u vidu oranica, od čega se oko $7 \%$ godišnje ne koristi (ostaje u vidu ugara ili neobrađenog zemljišta). Pored površina koje se ostavljaju za ugar, značajan deo površina pod livadama i pašnjacima se ne koristi zbog nepristupačnosti, zakorovljenosti ili usled ekonomske neisplativosti. Procene su da se svake godine ne obradi između 200 i 350 hiljada hektara oranica i livada, dok je površina nekorišćenog poljoprivrednog zemljišta sa pašnjacima znatno veća (Strategija, 2014).

Takođe, jedan od najvažnijih dokumenata vezan za sprovođenje mera agrarne politike jeste Nacionalni program za poljoprivredu za period 2018-2020. godine, i on predstavlja operativni program za sprovođenje poljoprivredne politike, koji sadrži mere klasi- 
fikovane kao mere direktnih plaćanja, mere za uređenje tržišta, kao i posebne podsticaje i kreditnu podršku u poljoprivredi. Program takođe definiše: polazišta i opšte i specifične ciljeve poljoprivredne politike, vrste mera i dinamiku njihovog prilagođavanja konačnom obliku primene sa predviđenim finansijskim iznosima i osnovnim pravilima za implementaciju, kao i indikatore za merenje ostvarenja ciljeva sa baznom i ciljnom vrednošću (Nacionalni program, 2017).

Prema projekciji budžeta, glavni izvor finansiranja poljoprivredne politike jeste budžet Republike Srbije. Kao dodatni izvor finansiranja mera uvode se budžetska sredstva na nivou jedinice lokalne samouprave, kao i budžetska sredstva na nivou autonomne pokrajine. Sredstva budžeta jedinice lokalne samouprave i autonomne pokrajine realizuju se kroz programe podrške sprovođenju poljoprivredne politike i politike ruralnog razvoja na teritoriji jedinice lokalne samouprave ili autonomne pokrajine i mogu se koristiti za finansiranje svih mera predviđenih Zakonom o podsticajima u poljoprivredi i ruralnom razvoju, osim pojedinih mera direktnih plaćanja. (Nacionalni program, 2017).

Analiza agrarnih mera predstavlja osnov za programiranje i planiranje poljoprivredne politike u narednom periodu (Đurić i dr., 2021). Ovo je jedan vrlo važan deo vrednovanja javnih politika u kom dolazi do ocenjivanja dosadašnjih učinaka neke od politika. Ta evaluacija predstavlja poslednji korak u stvaranju jedne politike, ali mnogo znači za donošenje neke nove, naredne politike. Analiza za potrebe izrade NPP izrađena je na bazi podataka o godišnjim budžetskim izdvajanjima za poljoprivredu u periodu 2008-2017. godine. U prethodnom periodu, posmatrano prema trendovima kretanja budžetskih sredstava za poljoprivredu, izdvajaju se tri karakteristična perioda:

- $\quad$ period od 2008. do 2011. godine, kada nakon maksimalno dostignutog budžeta (izraženog u EUR) u 2008. godini, dolazi do značajnog pada sredstava za poljoprivredu u 2009. godini i nakon toga do postepenog rasta;

- $\quad$ period od 2012. do 2014. godine, kada dolazi do izraženog rasta budžetskih sredstava za poljoprivredu u odnosu na prethodni period, i

- $\quad$ period od 2015. do 2017. godine, kada dolazi do pada izdvajanja za poljoprivredu u odnosu na prethodni period i delimičnog oporavka u 2017. godini (Nacionalni program, 2017).

$\mathrm{Na}$ narednom grafikonu možemo videti kakva su bila izdvajanja za poljoprivredu iz budžeta Republike Srbije za period od 2008-2017. godine. Ovo je dugačak period i može se iskoristiti za odgovarajuću analizu i zaključke koje država treba da donese prilikom usvajanja novih agrarnih politika. Uticaj države na agrarnu politiku se može videti kroz određivanja budžeta Ministarstva poljoprivrede i zaštite životne sredine.

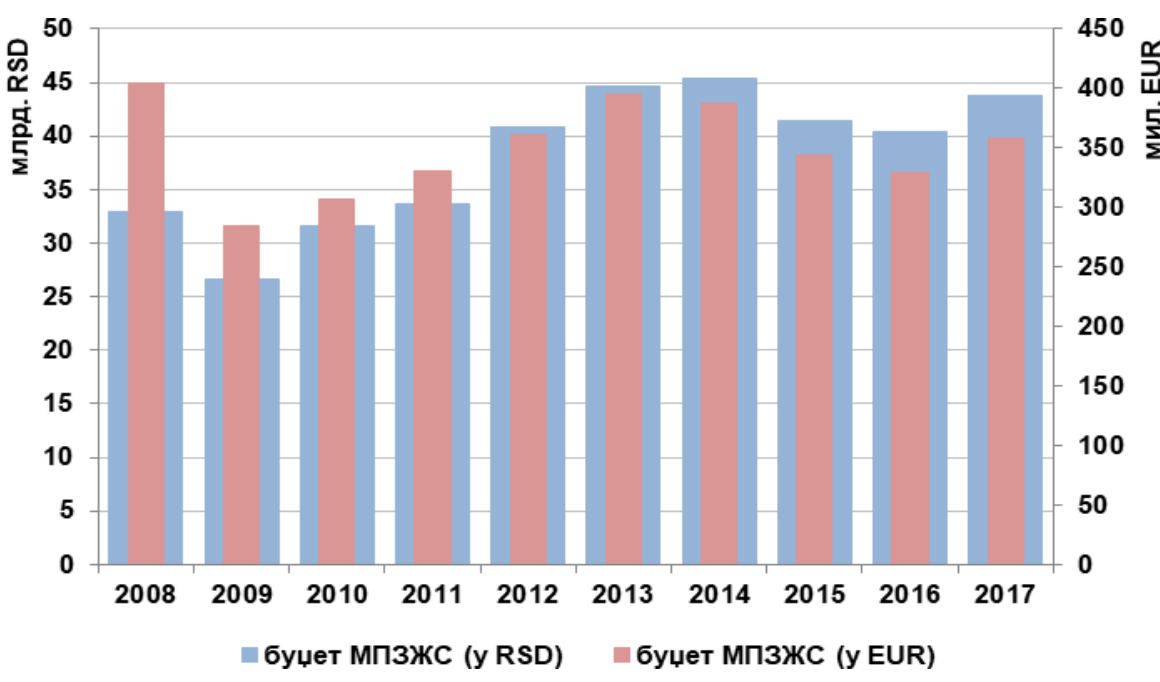

Grafikon 1. Budžetska izdvajanja za poljoprivredu (od 2008-2017. godine)

Graph 1. Budget allocations for agriculture (2008-2017)

Učešće budžetskih izdvajanja za poljoprivredu u ukupnom budžetu varira u posmatranom periodu, od 4,55\% u 2009. godini, do maksimalno dostignutog nivoa od 5,98\% 2014. godine. Ukoliko se posmatraju proseci posmatranih perioda, evidentan je najviši nivo prosečnog učešća, ostvaren u periodu 2012-2014. godine (prosečno učešće od 5,90\%), dok je najniže prosečno učešće sredstava za poljoprivredu u ukupnom budžetu zabeleženo u periodu 2015-2017. godine $(5,03 \%)$. Na narednom grafikonu je predstavljeno učešće budžetskih izdvajanja za poljoprivredu u ukupnim budžetskim sredstvima u periodu od 20082017. godine (Nacionalni program, 2017). 


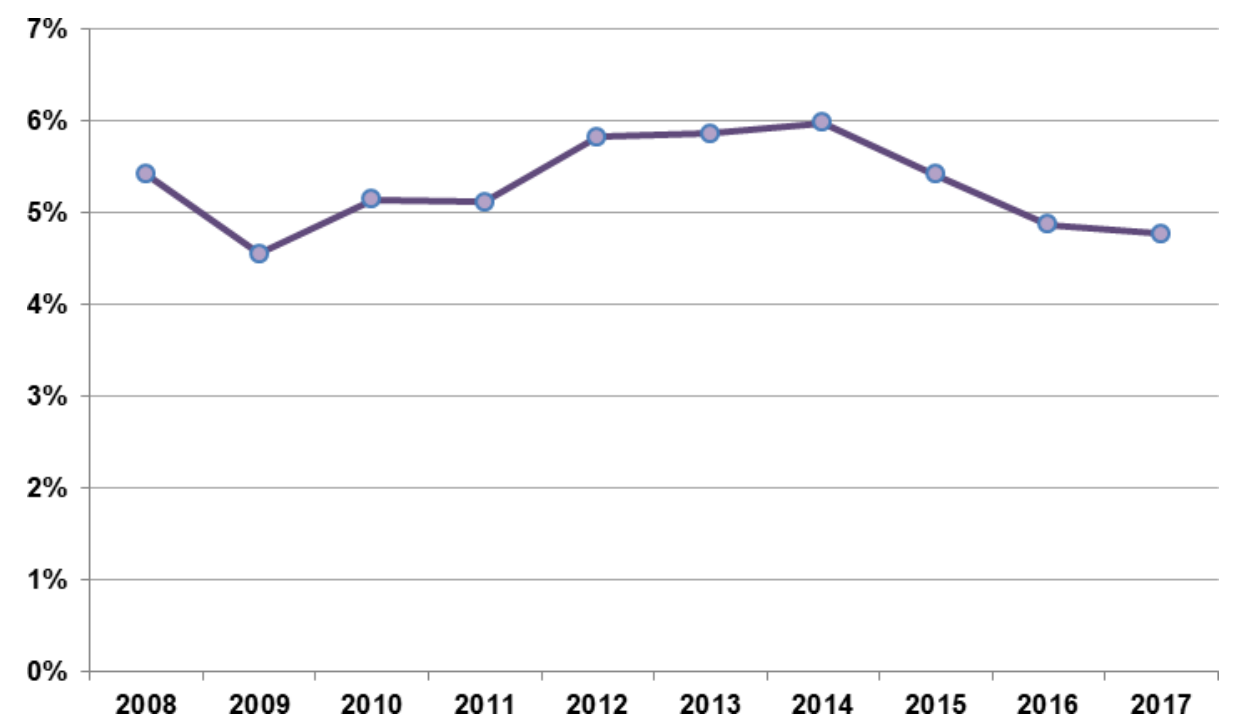

Grafikon 2. Učešće budžetskih izdvajanja za poljoprivredu u ukupnim budžetskim sredstvima u periodu od 2008-2017. godine

Graph 2 . Share of budget allocations for agriculture in total budget funds in the period 2008-2017

U budžetskim izdvajanjima za poljoprivredu dominiraju budžetska sredstva za podsticaje u poljoprivredi i ruralnom razvoju. Podsticaji u poljoprivredi i ruralnom razvoju propisani su Zakonom o podsticajima u poljoprivredi i ruralnom razvoju, koji podsti- caje klasifikuje kao: direktna plaćanja, podsticaje merama ruralnog razvoja, posebne podsticaje i kreditnu podršku. Na narednom grafikonu se može videti prosečno učešće pojedinih vrsta podsticaja u ukupnim podsticajima u poljoprivredi i ruralnom razvoju u periodu od 2013-2017. (Nacionalni program, 2017).

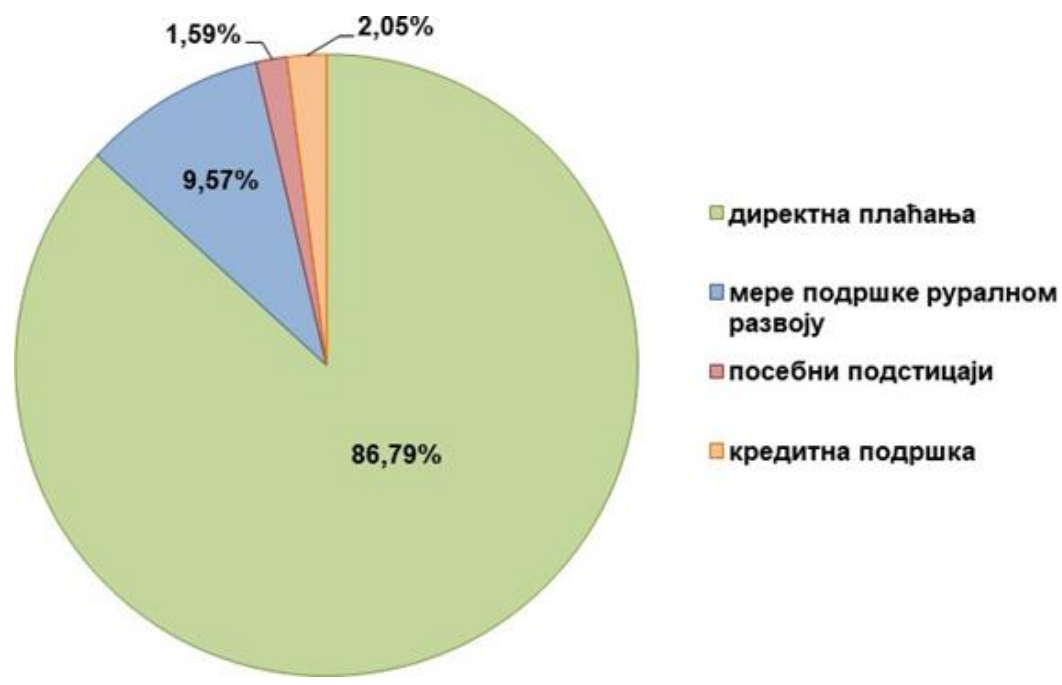

Grafikon 3. Prosečno učešće pojedinih vrsta podsticaja u ukupnim podsticajima u poljoprivredi i ruralnom razvoju u periodu 2013-2017. godine

Graph 3: Average share of individual types of incentives in total incentives in agriculture and rural development in the period 2013-2017

Što se tiče funkcionisanja poljoprivrede u poslednjih nekoliko godina, možemo reći da je u ukupnoj vrednosti poljoprivredne proizvodnje u 2019. godini biljna proizvodnja učestvovala sa $66,0 \%$, a stočarska sa $34,0 \%$. U odnosu na 2018. godinu, neto indeks fizičkog obima poljoprivredne proizvodnje manji je za $1,2 \%$. U narednoj tabeli je prikazana proizvodnja poljoprivrednih dobara i usluga u proizvođačkim cenama u periodu od 2009-2019. godine. 
Tabela 1. Proizvodnja poljoprivrednih dobara i usluga u proizvođačkim cenama u periodu 2009-2019. godine (miliona RSD)

Table 1. Production of agricultural goods and services at producer prices in the period 2009-2019 (millions RSD)

\begin{tabular}{|l|c|c|c|c|c|c|}
\hline Opis & 2009. & 2010. & 2011. & 2012. & 2013. & 2014. \\
\hline $\begin{array}{l}\text { Proizvodnja poljoprivrednih } \\
\text { dobara i usluga }\end{array}$ & 407850 & 466810 & 519959 & 502684 & 565521 & 584299 \\
\hline $\begin{array}{l}\text { Proizvodnja poljoprivrednih } \\
\text { dobara }\end{array}$ & 396220 & 455752 & 509125 & 491597 & 552078 & 569276 \\
\hline Biljna proizvodnja & 265101 & 328980 & 359103 & 324451 & 378832 & 390747 \\
\hline Stočarska proizvodnja & 131119 & 126771 & 150022 & 167146 & 173245 & 178528 \\
\hline $\begin{array}{l}\text { Proizvodnja proizvoda } \\
\text { stočarstva }\end{array}$ & 35266 & 37165 & 47248 & 53683 & 54353 & 55393 \\
\hline Poljoprivredne usluge & 11629 & 11058 & 10834 & 11087 & 13442 & 15023 \\
\hline
\end{tabular}

\begin{tabular}{|l|c|c|c|c|c|c|}
\hline Opis & 2015. & 2016. & 2017. & 2018. & 2019. & \\
\hline $\begin{array}{l}\text { Proizvodnja poljoprivrednih } \\
\text { dobara i usluga }\end{array}$ & 534779 & 589817 & 543746 & 589704 & 605291 & \\
\hline $\begin{array}{l}\text { Proizvodnja poljoprivrednih } \\
\text { dobara }\end{array}$ & 520965 & 574817 & 529890 & 574703 & 589978 & \\
\hline Biljna proizvodnja & 351927 & 419400 & 357056 & 398513 & 414528 & \\
\hline Stočarska proizvodnja & 169038 & 155417 & 172834 & 176190 & 175449 & \\
\hline $\begin{array}{l}\text { Proizvodnja proizvoda } \\
\text { stočarstva }\end{array}$ & 58026 & 51136 & 52356 & 61660 & 53480 & \\
\hline Poljoprivredne usluge & 13813 & 14999 & 13856 & 15000 & 15313 & \\
\hline
\end{tabular}

Najvažnije za razvoj agrarne politike je da postoje mere uz pomoć kojih će država utvrditi i sprovoditi agrarnu politiku. Pošto su mere kompleksne i od velikog značaja za razvoj poljoprivrede, delimo in na četiri grupe: zemljišna politika, ekonomske mere, tehničko-tehnološke mere i organizaciono-administrativne mere. $U$ kreiranju i sprovođenju ovih mera agrarne politike učestvuje veliki broj institucija: upravni i izvršni organi vlasti, poljoprivredni proizvođači (pojedinačno ili preko svojih asocijacija), naučni instituti i stručne službe.

Rezultati analiza ovakvih mera podrške poljoprivredi i ruralnom razvoju nas dovodi do brojnih zaključaka a to su: ne postoji sistemski pristup, efekti mera izostaju, očigledna je parcijalnost i pragmatičnost pristupa; mere ruralnog razvoja se tretiraju gotovo kao odvojena politika bez svesti o sinergetskim efektima; definisanje mera je prilično subjektivno i one su nedovoljno konceptualizovane; implementacioni mehanizmi su neprilagođeni, postoji deficit vertikalne i horizontalne koordinacije politike; ne postoji transparentnost sprovođenja mera i njihove kontrole, finansijski izvori u dugoročnijem periodu su nepoznati i nestabilni; kao i analitički rad koji je prepoznatljiv ali samo u određenim segmentima.

Sagledavajući probleme agrarne politike moramo naglasiti da bi razne, potencijalne investicije i donacije dale nadu domaćim poljoprivrednicima da ostanu na selu i da razvijaju svoje gazdinstvo i proizvodnju, negujući standard EU i uz očuvanje svoje životne sredine i ambijenta. Sektor poljoprivrede je veliki i veoma zahtevan i donosi sa sobom veliki broj propisa za čiju realizaciju je potrebno mnogo vremena, kvalitetnih obučenih institucija i velika kompetentna organizacija svih aktera agrarnog života naše države. Sve su to razlozi da se ozbiljno shvati značaj ove agrarne politike, šta ona sa sobom donosi i koliko je ona važna za srpsku posrnulu privredu. Potrebno je raditi na edukaciji i obrazovanju, ne samo poljoprivrednika i preduzetnika, već i celokupnog administrativnog aparata. Potrebno je pojačati marketing i promociju sela i turizma u cilju smanjenja migracija, koje su, godinama, sve izraženije, naročito kod mladih i visoko obrazovanih ljudi.

Od 2000. godine Evropska unija je odobrila izvoz hrane iz Republike Srbije. Od 2004. godine Republika Srbija izvozi više poljoprivrednih proizvoda u EU nego što uvozi. 2005. godine Republika Srbija je otvorila pregovore za članstvo u Svetskoj trgovinskoj organizaciji, od 2009. godine Republika Srbija jednostrano primenjuje Privremeni trgovinski sporazum sa EU, a na početku 2014. godine potpuno je izvršen proces liberalizacije uvoza proizvoda iz EU. Takođe je značajan i podatak da Republika Srbija izvozi $1 / 4$ ukupnog proizvoda u CEFTA. Sporazum o slobodnoj trgovini sa Ruskom Federacijom potpisan 2000. godine, a proširen 2009. godine, podrazumeva da $99 \%$ međusobne trgovine podleže režimu "slobodne trgovine“. Aprila meseca 2009. godine započeli su pregovori o slobodnoj trgovini sa članicama EFTA (Švajcarska, Norveška, Island i Lihtenštajn). 
Dakle, posle svih navedenih olakšica, Republika Srbija i dalje ima problem sa neuređenošću tržišta agrarnih proizvoda, nestabilnošću cena agrarnih proizvoda, jedan od najvećih problema je demografski problem agrarnog stanovništva, nepostojanje dugoročne Strategije za razvoj poljoprivrede i povratak mladih na oranice, korupcija, problem kreditiranja poljoprivrede i poljoprivrednih proizvođača, neorganizovana i nesigurna isplata subvencija registrovanim poljoprivrednim gazdinstvima. Svi ovi problemi su odlika ekonomskog sistema Republike Srbije. Politički činioci koji utiču na stvaranje i identitet jednog političkog sistema su svi činioci koji neposredno deluju kao politički subjekti, odnosno svi oni činioci koji su sastavni deo jednog društva (Ljubojević, Petrović, 2019).

Republika Srbija pod uticajem globalne ekonomske krize od 2008. godine, pa i danas pod uticajem pandemije korona virusa, ima težak zadatak, a to je da se novčana sredstva ulože u proizvodnju odjednom i to u izuzetno velikom obimu, poštujući prirodu proizvodnje; što duži period zadržavanja uloženih sredstava na raspolaganju poljoprivrednom gazdinstvu; insistiranje na organskoj proizvodnji hrane; primena adekvatne kreditne politike od strane nacionalnih banaka pod patronatom Narodne banke Republike Srbije; investiranje u povećanje stočnog fonda; smanjenje uvoza proizvoda koje država može da obezbedi podsticanjem domaćih proizvođača.

Novi oblik pravno-političkog delovanja, ponašanja, vrednovanja i prihvatanja realiteta života i okolnosti socijalne geneze i evolucije jeste stvaranje novih kulturološko-vaspitnih ustrojstava (Blanuša i dr., 2020). Politička saradnja i prihvatanje evropskih vrednosti i standarda u oblasti političko pravnog uređenja države i društva, razvoj demokratije, funkcionisanje pravne države i vladavine prava kao i poštovanje ljudskih prava i osnovnih sloboda deo su zajedničke tradicije prihvaćene od strane svih, ili skoro svih država evropskog kontinenta, te predstavljaju nadgradnju ekonomske integracije mirovnog projekta koji se razvija na tlu Evrope od 1951. godine (Petrović, Vasilkov, 2021).

U razvoju agronomije značajnu ulogu zauzimaju i lokalne samouprave, kao oblici decentralizovane vlasti. Zadatak lokalnih samouprava je da se bore i stvaraju perspektivu lokalnom stanovništvu, a u ovom slučaju poljoprivrednim proizvođačima kroz izgradnju infrastrukture koja je imanentna 21. veku. Lokalne vlasti u većini zemalja su u poslednje dve decenije uložile veliki napor da građanima obezbede odgovarajuće uslove za život, obezbeđenjem kvalitetnih javnih dobara i usluga, kao što su stanovanje, obrazovanje, snabdevanje gasom i električnom energijom, odgovarajuća zdravstvena politika i mnoge druge korisne usluge (Blanuša, 2021). Značaj zdrave životne sredine za normalno funkcionisanje ljudskih života poznat je od davnina, a njeno zagađenje koje je poprimilo ogromne razmere prepoznato je kao gorući problem; svest o šteti koju čovek svojim svakodnevnim aktivnostima nanosi životnoj sredini polako se podiže na viši nivo i to iz razloga što je životna sredina počela čoveku vraćati „milo za drago“ (Lazić i dr., 2021).

\section{ZAKLJUČAK / CONCLUSION}

Republika Srbija ima neadekvatnu ulogu u razvoju vlastite poljoprivrede, a to znači nedostatak nacionalne strategije razvoja i nizak agrarni budžet. Politička uloga državne organizacije ogleda se u činjenici da bez obzira kako država bila organizovana, ona će uvek težiti da vršenjem političke funkcije ostvari i učvrsti svoje interese. Tretiranje poljoprivrede kao socijalnog amortizera društva dovodi do deagrarizacije i demografskog pražnjenja sela, što pokazujuju podaci o broju neoženjenih muškaraca i neudatih žena koje žive na selu. Takođe uznemirujuć je i podatak da tek oko $14 \%$ dece uzrasta od tri do pet godina pohađa predškolsko obrazovanje. Neizgrađena infrastruktura, težak prilaz školama i drugim obrazovnim institucijama, kao i nedostatak zdravstvene nege u selima Srbije osnovni su parametri efekata mera i strategija koje preduzima Republika Srbija, a s ciljem razvoja agrara. Potencijal sa kojim raspolaže Republika Srbija, posebno AP Vojvodina treba iskoristiti u svrhu investiranja u poljoprivredu, usvajanje i sprovođenje Nacionalne strategije za razvoj poljoprivrede, a da to ne bude politički dokument, već pravni osnov za liberalniji pristup kreditiranju poljoprivrednih proizvođača, podrška kako velikim tako i malim proizvođačima, plansko krčenje plodnog a zapuštenog zemljišta, intervencija države u staračkim domaćinstvima i pružanje nužne pomoći koja bi kao takva bila definisana pomenutom strategijom, donošenje paketa mera koje mogu biti preventiva u slučaju posledica izazvanih klimatskim promenama, stvaranje novog koncepta upravljanja poljoprivredom, donošenje rebalansa budžeta, stvaranje dugoročnog plana subvencionisanog vraćanja mladih na selo i razvoj seoskog turizma kroz organsku proizvodnju hrane, rad na politici poslovnog povezivanja poljoprivrednih subjekata, obezbeđivanje skladištenja određenih proizvoda (poput malina) i stvaranje politike konkurentnosti kvalitetom proizvoda, modernizacija i digitalna kontrola useva, kao i plansko stvaranje otkupnih cena poljoprivrednih proizvoda pre setve, kako bi proizvođači jasno znali u koju poljoprivrednu kulturu žele da investiraju. Sve navedene mere su predlog resornom ministarstvu i Vladi Republike Srbije, a na osnovu teorijskih, ali i praktičnih saznanja do kojih smo za 
potrebe ovog rada došli putem intervjua. Republika Srbija ima apsolutno pravo, ali i obavezu da stane iza strateškog poduhvata u agrarnoj politici i da stepen uspešnosti poljoprivredne proizvodnje podigne na poziciju koja pripada našoj državi, s obzirom na analizu sveukupne meliorizacije zemljišta našeg geografskog položaja.

\section{LITERATURA / REFERENCES}

[1] Blanuša A. (2021), Izazovi upravljanja i razvoja grada Beograda i velikih evropskih gradova. Dosije studio, Beograd, 284 str.

[2] Blanuša A., Vasilkov Z., Petrović S. (2020), Pravno-politički aspekti upravljanja državom u 21. veku. Politička revija, 63(1), 263-283.

[3] Drummond H.E. et al. (2001), Agricultural Economics, Prentice-Hall, New Jersey, pp. 183.

[4] Đurić K., Ivanišević D., Jahić M., Prodanović R. (2021), Mere agrarne politike u funkciji održivog ruralnog razvoja Republike Srbije, Ecologica, 28(102), 264-270.

[5] Lazić D, Miladinović Bogavac Ž., Vuković J., Damnjanović A., Petrović S. (2021), Krivičnopravna zaštita životne sredine u Republici Srbiji i njeno usklađivanje sa zakonodavstvom Evropske unije, Ecologica, 28(103), 473-480.
[6] Ljubojević R., Petrović S. (2019), Ključni faktori koji utiču na razvoj političkog sistema Republike Srbije, Srpska politička misao, 65(3), .217-232.

[7] Pejanović R., Cvijanović D., Njegovan Z., Tica N., Živković D. (2009), Problemi poljoprivrede Republike Srbije i mere za prevazilaženje krize, Ekonomika poljoprivrede, 56(2), 221-230.

[8] Petrović S., Vasilkov Z. (2021), Pristupanje Republike Srbije Evropskoj uniji - proces bez kraja, Politička revija, 68(2), 183-199.

[9] Strategija razvoja poljoprivrede Srbije, Službeni glasnik RS, broj 78/2005.

[10] Strategija poljoprivrede i ruralnog razvoja RS za period 2014-2024.godine, Službeni glasnik RS, broj 85/14.

[11] Zaključak i Nacionalni program za poljoprivredu za period 2018-2020. godine, Službeni glasnik $R S$, broj $120 / 17$

[12] Žikić S., Nestorović M., Stevanović M. (2021), Ekonomski, ekološki i društveni aspekti održivog upravljanja obnovljivom energijom. Ecologica, 28(101), 57-65.

[13] Žikić S., Trifunović D., Ranđelović M. (2020), Zadovoljstvo poslom u funkciji održivog menadžmenta hotelskog sektora Stare planine, Ecologica, 27(99), 530-537. 